=

DOI: $10.31857 / \mathrm{S} 032103910015612-6$

\title{
ON THE ORIGIN OF THE EARLY CHRISTIAN PAINTINGS IN CHERSONESOS TOMBS
}

\author{
Irina A. Zavadskaya \\ V.I. Vernadsky Crimean Federal University, Simferopol, Russia \\ E-mail: zavadskaya_irina@mail.ru
}

The decorative programs of eleven painted tombs of Chersonesos (south-west Crimea), which include mainly floral-plant motifs, images of birds, imitation marble facings and in several tombs also a Christogram and a human figure, correspond to the iconography of early Christian funerary paintings of the Late Roman Empire. They date back to the last quarter of fourth century or the beginning of the fifth century AD. The article revises the traditional concept of the Syro-Palestinian origins of Chersonesos paintings. Based on their style, the specifics of the artistic repertoire, compositional features and the decorative system as a whole, the author concludes that the closest parallels to the Chersonesos monuments can be found in the eastern Balkan provinces of Thrace and Dacia and in the Western Asia Minor. Some features inherent in the Chersonesos paintings allow us to consider them as a local Chersonesos variant of the provincial East Balkan and West Asia Minor Late Antique funerary painting.

Keywords: Chersonesos, painted tombs, early Christian funerary paintings, Thrace, Asia Minor

Author. Irina A. Zavadskaya - PhD (History), Associate professor, Senior researcher at V.I. Vernadsky Crimean Federal University, Research Center for Archaeology and History of Crimea.

The work is implemented within the framework of the state assignment of the Ministry of Education and Science of the Russian Federation No. FZEG-2020-0029 on "The influence of the Byzantine Empire on historical processes in medieval Crimea".

This article is a translation of: Завадская И.А. О происхождении раннехристианских росписей в склепах Херсонеса. Journal of Ancient History [Vestnik drevney istorii] 81/2 (2021), 439-462. DOI: 10.31857/S032103910010623-8. 
$\mathbf{P}$ ainted tombs have a special place in the history of late-antique Chersonesos. They are among the earliest Christian monuments of the city and of great importance for reconstructing the initial stage of its Christianization. Being an integral part of the world fund of early Christian art, the burial painting of Chersonese carries information about the origin and ways of penetration of a new artistic tradition in the main ancient center of Southwestern Taurica.

The painted tombs of Chersonesos belonged to one of the most common types of rock-cut burial structures with dromos and a small quadrangular chamber with niche beds in the back wall and sidewalls. In different parts of the necropolis, more than 400 such tombs ${ }^{1}$ have been discovered, of which only 13 contain the remains of polychrome wall paintings. Most likely, such ornamental decoration of burial structures was quite rare for Chersonesos.

The paintings of the two tombs ( $1894^{2}$ and No. 2/2008) are radically different from the rest of the group: they are the earliest and are associated with pagan cults. In the tomb of 1894 , dated $3^{\text {rd }}$ century AD, by M.I. Rostovtseff, mythological stories were presented with a dancing thyiad and a scene of the abduction of a young man the deceased by winged genius ${ }^{3}$. Plot compositions with scenes of hunting and two horsemen in tomb No. 2/2008 of the end of $2^{\text {nd }}-$ beginning of $3^{\text {rd }}$ century AD can be associated with the cult of the Thracian horseman ${ }^{4}$, who appeared in Chersonesos together with Roman legionaries - natives of the Danube lands 5 . The painting of each of these tombs is unique to Chersonesos. They reflect the views of supporters of different syncretic cults, have different plots and compositional solutions. The level of their execution is also different. Most likely, they were created by order of visiting masters representing different art schools. Therefore, there is no reason to talk about the existence of a local art center in Chersonesos in the $2^{\text {nd }}-3^{\text {rd }}$ centuries ${ }^{6}$, having only two different samples of funerary painting in terms of plot, style, and quality of execution.

The remaining 11 painted tombs of Chersonesos belonged to a completely different artistic tradition and cultural and religious environment. A detailed description and stylistic analysis of the eight tombs discovered in the second half of the $19^{\text {th }}$ - early $20^{\text {th }}$ century were included in a monograph by M.I. Rostovtzeff published plans, drawings, and reconstructions of murals made by the artist M.I. Skubetov, and several colored copies by M.V. Farmakovsky ${ }^{7}$. Since then, these monuments have hardly been

\footnotetext{
${ }^{1}$ According to the calculations of V.M. Zubar', 411 tombs with niche beds were discovered in the Chersonesos necropolis by the end of the 1970s (Zubar' 1982, 25-29, 33). Further on, new tombs of the same type were researched in different parts of the necropolis, but the total number has not yet been specified.

${ }^{2}$ It is the custom to include the year of their discovery into the names of the Chersonesos tombs.

${ }^{3}$ Rostovtzeff 1914, 442-447.

${ }^{4}$ Rishnjak, Sadova, Turovs'kij, Filippenko 2012, 26-35, 53-79.

${ }^{5}$ Buyskikh 2008, 238; Zubar' 1994, 65-67, 94-95.

${ }^{6}$ Rishnjak, Sadova, Turovs'kij, Filippenko 2012, 79.

${ }^{7}$ Rostovtzeff 1914, 449-507.
} 
investigated ${ }^{8}$. Three new painted tombs have been discovered and studied in our time, two in $1998-1999$ and one in 2003/2006 9

Even though the painting of each of the 11 tombs is largely individual and is generally not repeated anywhere in detail, all these paintings are similar in style, a set of picturesque elements, and a colorful palette. The images of trees, flowers, garlands, fruit, vines, birds, burning candles, decorative panels, and chrisms and human figures discovered in several tombs fully correspond to early Christian funerary art's iconography developed from the Greco-Roman artistic tradition. As a result of a recent discussion regarding the inception of painted tombs in Chersonesos, the dates suggested by M.I. Rostovtzeff more than a century ago were confirmed ${ }^{10}$. Considering the early Christian nature of the painting and the coins found in the tombs, he attributed the paintings of most of the tombs to the second half of the $4^{\text {th }}$ century, although he did not rule out that some could have appeared in the $5^{\text {th }}$ century ${ }^{11}$. Many monuments of early Christian funerary paintings from different areas of the Late Roman Empire, which are closest to the Chersonesos, date back from the middle/second half of the $4^{\text {th }}-$ beginning/first half of the $5^{\text {th }}$ century ${ }^{12}$.

If the question of the inception of the painting of the Chersonesos tombs seems quite definite, although in a relatively wide chronological range, then the problem of their origin is still relevant and open. The purpose of this article is to consider this problem at a modern level and taking into account a wide range of monuments of burial painting of the Late Roman Empire, to identify the closest parallels and find the likely ways of penetration of this artistic tradition in this remote center of the early Christian ecumene.

For the first time, the origin of the early Christian Chersonesos paintings was considered by M.I. Rostovtzeff. After conducting a deep stylistic analysis of the Chersonesos paintings and comparing them with the monuments known at that time, similar in character, he formulated several fundamental conclusions for future research. First of all, he pointed out the unity of the style and system of the painting of the entire group of Christian tombs of Chersonesos. He was convinced that the simultaneity and absence of stylistic predecessors precluded the possibility of their local origin: "The painting of this group of Christian burials could not have originated in Chersonesos and developed from the local tradition... but was rather imported and borrowed ${ }^{13}$." The researcher also noted the strict observation of a certain "developed pattern," following the same system that divides the wall horizontally into a "heavy frieze-like bottom" with marble inlay imitation and a "light top, filled

\footnotetext{
${ }^{8}$ At present, the location of only three tombs is known. Published by M.I. Rostovtzeff. Modern explorations have shown that the entrance to the tomb of 1903 was covered with earth, and its painting condition is unknown. The painting of the tomb of 1853/1904 is completely lost. Only some picturesque fragments have been preserved in the tomb of 1905 (Rishnjak, Sadova, Turovs'kij, Filippenko 2012, 101).

${ }^{9}$ Zubar', Khvorostyanyy 2000; Stupko, Turovskiy, Filippenko 2007, 189-192.

${ }^{10}$ Diatroptov 2002; Zavadskaya 2005; 2009; 2013, 47-61; Khrushkova 2008; Turovskiy, Filippenko 2008.

${ }_{11}$ Rostovtzeff 1914, 451-479.

12 Miyatev 1925; Pillinger, Popova, Zimmermann 1999; Valeva 2001; Marki 2006; Rousseau 2019; и др.

${ }^{13}$ Rostovtzeff $1914,440-441,484-486$.
} 
with flowers and birds." At that time, he noted that the system is "completely independent and original" and is not repeated in other famous monuments ${ }^{14}$.

The inlay and floral styles that were used in this system, according to M.I. Rostovtzeff, had undoubtedly Eastern origin. He believed that the floral style was already known in pre-Hellenistic Egypt, and the roots of marble inlay, which was a derivative of the Eastern Hellenic system, namely the first Pompeian style, "should be found in areas that were under the cultural influence of Mesopotamia." Both styles were combined in one system in a "purely mechanical combination" in the era of the early Roman Empire, and M.I. Rostovtzeff visualised the closest parallels to the already established system either in the Syro-Palestinian East, or in the field of monuments, the connection of which with Syria and Palestine seems very likely." This system was also used in the painting of Chersonesos tombs, which, according to the scientist, indicates "a close connection of the first Christians of the city not with Byzantium or the Balkan Peninsula," but with the more distant Syro-Palestinian Christian community ${ }^{15}$.

M.I. Rostovtzeff saw the confirmation of the "connection of Chersonesos with the Syro-Palestinian south" in the Ives of the Bishops of Chersonesos, according to which the first preacher-bishops who arrived in Chersonesos during the Diocletian era and were martyred here, were the messengers of Hermon of Jerusalem, the bishop of the Church of Jerusalem. Considering the criticism of contemporary scholars who denied the historicity of the consecration of preachers as bishops and their sending by the head of the Jerusalem Church, M.I. Rostovtzeff nevertheless believed that this part of the Lives was based on the tradition preserved among local Christians about the first martyrs, "alien missionaries" from Syria or Palestine ${ }^{16}$.

Hereafter, many researchers quite reasonably questioned the hagiographic message about the sending missionaries from Jerusalem, whose church at the dawn of the spread of Christianity did not have much influence and opportunities for such initiatives ${ }^{17}$. The names of the first martyrs were most likely associated with Jerusalem in the era of the creation of the Lives photograph, which dates, as a rule, not earlier than the $6^{\text {th }}-7^{\text {th }}$ centuries, i.e., much later than the paintings appeared. Despite the well-founded criticism of the historical component, the question of the origin of Christian paintings has long been either not discussed, or a priori accepted the conclusion of M.I. Rostovtzeff about their Syro-Palestinian origins ${ }^{18}$. It was only at the beginning of this century that new perspectives on this problem emerged. According to P.D. Diatroptov, the closest parallel to the Chersonesos paintings is represented by the paintings of the Christian tombs of the $\mathrm{Ne}$ cropolis of Saint Sofia Church ${ }^{19}$. Basically, the Balkan and Asia Minor analogies were used to consider the problems of chronology and genesis of the Chersonesos paintings, in my opinion, pieces ${ }^{20}$. Considering the painting of early Christian tombs in the Crimea

\footnotetext{
${ }^{14}$ Rostovtzeff $1914,484$.

${ }^{15}$ Rostovtzeff 1914, 500-503.

${ }^{16}$ Rostovtzeff 1914, 504-506.

17 Meshcheryakov 1978, 128; Diatroptov 1986, 131-132; Zuckerman 1994, 547; Zubar', Khvorostyanyy 2000, 91; et al.

${ }^{18}$ Diatroptov 1986, 132; Zubar', Khvorostyanyy 2000, 87.

${ }^{19}$ Diatroptov 2002, 34-35.

${ }^{20}$ Zavadskaya 2005; 2013, 47-61.
} 
in the context of the general development of early Christian burial art, L.G. Khrushkova concluded that the Crimean monuments can be attributed to the zone "between East and West", while noting their proximity to the Pontic-Balkan region ${ }^{21}$.

Despite the emergence of new research on the origin of the paintings of the Chersonesos tombs, there are also supporters of the idea of the Middle Eastern origins of these monuments among national researchers. Thus, A.E. Filippov, drawing as the only analogy the frescoes of the baptistery of the family chapel in Dura-Europos, stated that the paintings of the Chersonesos tombs are "a rare example of a Middle Eastern version of early Christian painting 22." Based on the supposed "stylistic proximity," primarily in the images of male figures in two Chersonessos tombs (1853/1904 and 1909) and the Myrrhophores on the northern wall of the baptistery in Dura-Europos, the author believes that these monuments "could have arisen almost in parallel." Taking as a reference point the time of the creation of the frescoes of the delubrum of Dura-Europos (between 232 and 256), as well as based on an arbitrary, highly subjective assessment of the composition and style of the Chersonesos paintings, the author offers an absolutely far-fetched "scale of relative chronology," within which he establishes the sequence of the appearance of the Chersonesos painted tombs from the first half of the third century to the beginning of the fourth century ${ }^{23}$.

Such an early date is baseless in the context of the history of the city itself and the spread of Christianity in it and in the context of the history of Christian funerary painting throughout the Roman Empire. It is enough to note that the image of the Christogram in a wreath as a symbol of the triumphal victory over death, recorded on the vaults of several Chersonesos tombs, appeared in Christian monuments only in the $4^{\text {th }}$ century, during the era of Constantine the Great, most likely after the Edict of Mediolan 313 AD, and had been spreading since the middle of that century ${ }^{24}$.

The figures of young men from the Chersonesos tombs and the Myrrhophores walking to the Holy Sepulchre in the Baptistery of Dura-Europos ${ }^{25}$ have different meanings and artistic solutions. They are united only by the en face position and the burning candle in their hands.

The frontal static presentation of figures is one of the distinctive features of the new style, which was the result of the cardinal transformations in art from the end of the $2^{\text {nd }}$ to the beginning of the $4^{\text {th }}$ century, called by Ernst Kitzinger the stylistic revolution, which led to the gradual rejection of the classical Greco-Roman traditions in art throughout the empire $^{26}$. In late-antique burial paintings, the frontal characters are known everywhere from Rome and Naples to the Middle East and North Africa. Sometimes there are figures with a candle in their hands. In the tomb of Aelia Arisuth of the second half of the $4^{\text {th }}$ century from Gargaresh (Tripoli, Libya), two servants with burning candles in their

${ }^{21}$ Khrushkova 2008, 129.

${ }^{22}$ Filippov 2009, 315. This statement was supported by some authors without any analysis (Bolgov 2004, 18; Fomin 2014, 38-46).

${ }^{23}$ Filippov 2009, 312-315.

${ }^{24}$ Valeva 1998; Khrushkova 2005, 415-416; Zavadskaya 2009, 92-93; Patrich 2016, 275-276.

25 Pergola 2010.

${ }^{26}$ Kitzinger 1977, 7-19. 
hands on both sides of the burial niche were depicted ${ }^{27}$. Functionally, these figures are quite comparable to the characters from the Chersonesos tombs, although they are executed in a completely different way and can not have a direct genetic connection. Nevertheless, these paintings indicate that the image of the figure with a candle was known in late antique art and was embodied by artists in different regions ${ }^{28}$.

Thus, the search for a direct connection between the paintings of the Chersonesos tombs and the baptistery at Dura-Europos cannot be productive. They show some trends common to late-antique art, but they belong to different periods and monuments different in nature. The first-ever iconographic program of iconographic scenes, presented on the walls of the Syrian baptistery in the second quarter of the $3^{\text {rd }}$ century, largely anticipated the further development of church decorative painting. Appeared more than a hundred years after the destruction of Dura-Europos, in the last quarter of the $4^{\text {th }}$ beginning of the $5^{\text {th }}$ century, the Chersonesos paintings decorated the burial structures, which predetermined their decorative program, radically different from the frescoes of Dura-Europos both in ideological content and in the artistic embodiment.

The problem of the origin of the paintings of the Chersonesos tombs can be considered in two different contexts, namely, in the context of the history of the formation of the art system and the style of painting in general, as well as the history of the appearance of this system established in Chersonesos. In his fundamental research, M.I. Rostovtzeff focuses primarily on the history of the artistic styles that formed the painting system and individual pictorial motifs. The monuments considered by him from Italy to the Middle East and Egypt belong to a wide chronological range - from Hellenism to the $4^{\text {th }}-5^{\text {th }}$ centuries AD. And, thus, they can illustrate the long path of formation of the decorative system embodied in the Chersonesos tombs and examples of the motifs used in it.

Supporting the idea of the Middle Eastern origin of this system, M.I. Rostovtzeff nevertheless noted its penetration into the West, in particular, in the paintings of the catacombs in Rome, Syracuse, and Naples. Especially in this respect, he singled out the series of tombs of the Necropolis of Saint Sofia Church, of which only the tomb with the archangels was published at that time. According to the scientist, "the scheme of their painting... is the same as in our tombs ${ }^{29}$." However, he made the conclusion about the origin of this system in favor of the Syro-Palestinian East.

The position of M.I. Rostovtzeff is quite understandable, considering that he, like many of his contemporaries, was strongly influenced by the innovative concept of J. Strzygowski about the dominant role of the Hellenized East in the formation of late Antique and early Christian art and, subsequently, medieval art in Western Europe ${ }^{30}$. The heated controversy between the defenders of the ideas of Orientalism and. Strzygowski and the romanists, supporters of romano-centrism, largely determined the history of late antique art as an independent discipline ${ }^{31}$. Later, however, the search for

${ }^{27}$ Bianchi Bandinelli 1970, 264, fig. 242; Zavadskaya 2005, 275, рис. 19.

${ }^{28}$ In his fundamental research, M.I. Rostovtzeff cites as an example a fragment of Coptic fabric depicting a man in a tunic holding a candle holder with both hands (Rostovtzeff 1914, 491, fig. 91).

${ }^{29}$ Rostovtzeff 1914, 487-489, 493, 501.

${ }^{30}$ Strzygowski 1901.

${ }^{31}$ Elsner 2002. 


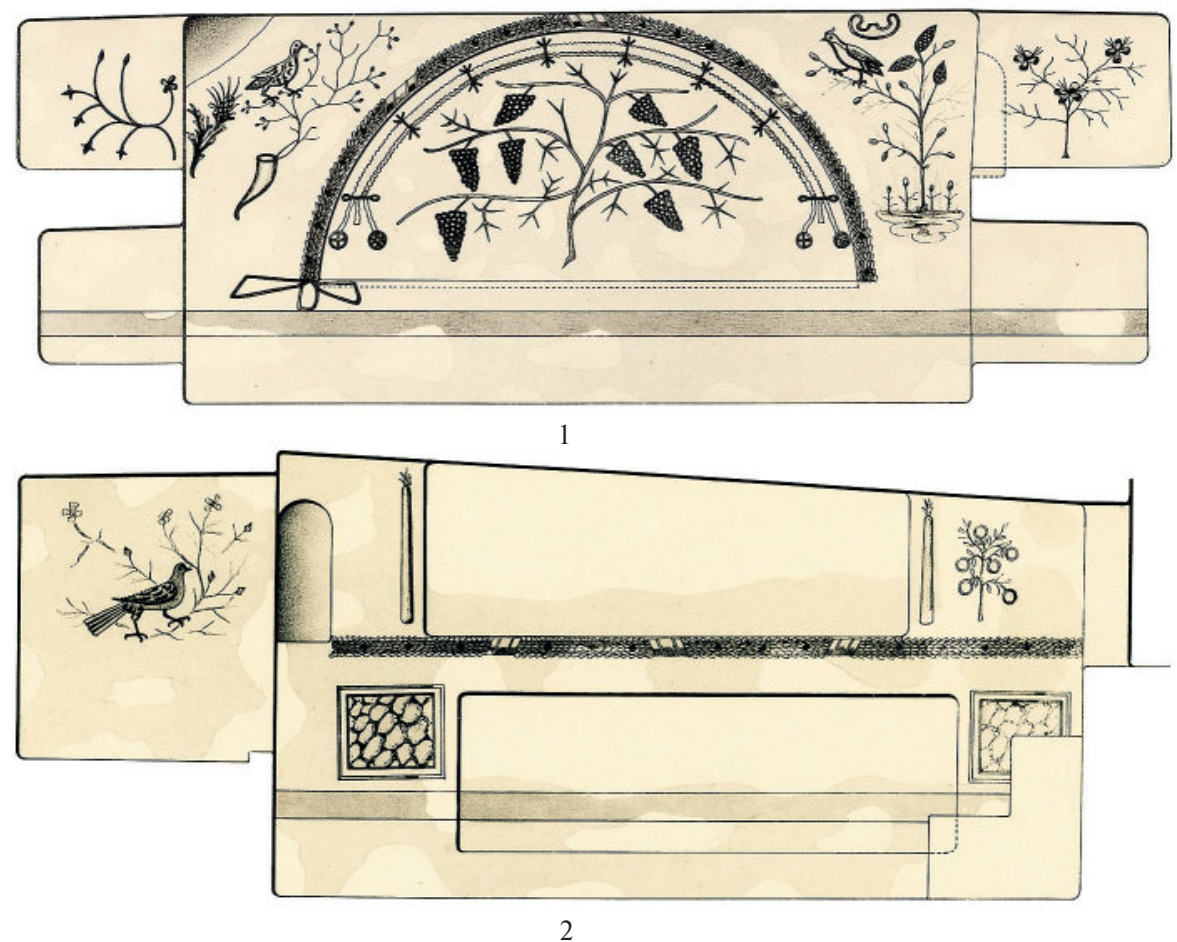

Fig. 1 Chersonesos. Painting of the tomb of 1905: 1 - back wall; 2 - right wall (Fig. by: Rostovtzeff 1913, Tables 107-108)

the causes of the transformations in art, associated with the collapse of the classical canon, went beyond the "East or West" dilemma, which lost its strength and relevance. A. Grabar believed that the origins of the "deformation" of Greco-Roman art should be sought in the peripheral provinces of the empire and border countries, not only in the east but also in the west - "from Mesopotamia and Armenia to Egypt and Great Britain," as well as Spain. In his opinion, the artists of these areas, which he called the "third world of antiquity," imitating classical models quite clumsily, sometimes disfiguring them, created a completely different system of artistic values ${ }^{32}$. E. Kitzinger, recognizing the possible influence of the peripheral regions of the Roman world on the development of late-antique art in Rome itself, focuses on the "mass revival of the local plebeian tradition," which has always existed both on the outskirts of the empire and in Rome. In the conditions of a deep internal crisis in the late-antique empire, the classical canons and forms in the art are being re-evaluated, which cease to be significant and gradually replaced by the aesthetics of the so-called "sub-antique", i.e., plebeian, folk art. This process, which Kitzinger called the stylistic (and aesthetic) revolution, was ubiquitous and, according to the scientist, "a broad, irresistible stream encompassed everyone and everything" 33 from Western Europe to Mesopotamia. Since the end of the $2^{\text {nd }}$ century,

\footnotetext{
${ }^{32}$ Grabar 1972, 10, 20, 24.

${ }^{33}$ Kitzinger 1977, 10-11, 17.
} 
and especially in the $3^{\text {rd }}-4^{\text {th }}$ centuries, in the works of sculpture and painting, including burial painting, the features of the sub-antique style have been increasingly manifested heavy, angular, frontally located, planar figures with distorted proportions, with abrupt rough movements and gestures, the gradual rejection of drawing details, simplification of the composition, degradation, and disappearance of elements of the architectural style and signs of the landscape, inconsistency of scale within the composition, increasing patterning, and abstraction.

At this time and in these conditions, Christian art was born, which took both a rich arsenal of pictorial motifs and symbols and the existing stylistic techniques from the contemporary art culture. This was fully reflected in the funerary paintings of the $4^{\text {th }}-$ beginning of the $5^{\text {th }}$ century, whose monuments have been preserved from Italy to the Middle East and North Africa.

Almost everywhere, the main idea of the paintings of early Christian burial structures was primarily to express hope for salvation after death, faith in the resurrection of the dead, and their stay in the Kingdom of Heaven ${ }^{34}$. In different centers and regions, decorative programs inspired by this general idea were formed under the influence of certain artistic traditions, resulting in which, in addition to common features, they acquired their own special regional features.

As already mentioned, a characteristic feature of the decorative painting system of the Christian tombs of Chersonesos is the combination of elements of floral and inlay styles, which divide the wall horizontally into two parts. The lower part of the walls consisted of rectangles (orthostats), usually imitating marble cladding. This design is recorded in six tombs $(1903,1853 / 1904,1905$, No. 2/1907, 1909, and No. 1/1998-1999). The set of decorative motifs that filled the upper part of the walls was relatively poor and unique for each tomb. Almost all of them were drawn in the spirit of the late antique art, rather conventionally, sometimes schematically, without transmitting the perspective and with a limited color palette. The compositions are straightforward and not overloaded with decorative elements. The most popular were images of garlands and wreaths tied with ribbons and strings with bows at the ends. In different tombs, two kinds of garlands and similar wreaths are registered: gray-green dried laurel leaves with interwoven red shamrocks and red flower petals ${ }^{35}$. The compositions of three tombs included a lush vine or branches with clusters of grapes (tombs of 1853/1904, 1905, 1909); two of them also had small trees with fruits or flowers (tombs of 1853/1904 and 1905) (Fig. 1). Trees without leaves and fruits were also present in the painting of the tombs in 1903. In almost all of the tombs, except the two poorly preserved ones (Nos. 1 and 2/1907), birds were painted - mostly pigeons, sitting on branches and/or peacocks. Flowers as separate motifs are presented in a red-yellow four-petalled rosette (1905, tomb on the land of N.I. Tour, 2003/2006) (Fig. 2) and a red open flower on a stem with leaves (No. 1/1998-1999) (Fig. 3). The overturned basket of flowers in tomb No. 2/1998-1999 is also a floral motif.

${ }^{34}$ Grabar 1946, 8-11.

${ }^{35}$ Laurel garlands were found in almost all of the Chersonesos tombs before the revolution (1853/1904, 1905, № 2/1907, 1909, 1912, the tomb on the land of N.I. Tour), four of them also had wreaths of the same type. Red flower garlands are known in three tombs: Nos. 1 and 2/1998-1999 and 2003/2006. 


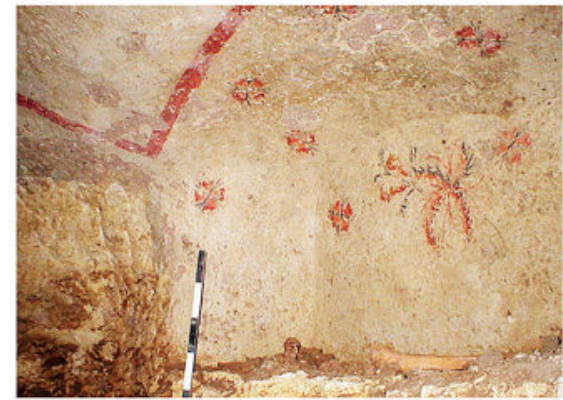

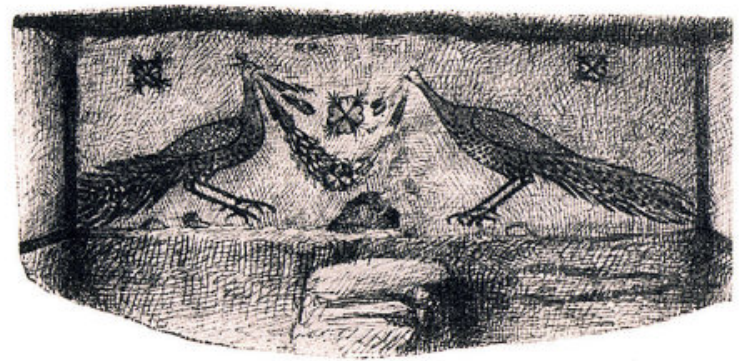

2

Fig. 2 Chersonesos. Tomb paintings: 1 - the back wall of the tomb of 2003/2006 (photo by: Stupko, Turovskiy, Filippenko 2007, fig. 2a); 2 - the back wall of the tomb on the land of N.I. Tour (fig. by: Rostovtzeff 1914, fig. 88)

Chersonesos paintings have rare images of people. The only scene with two figures, a man and a woman, near the schematically depicted city on the right wall of the tomb on the land of N.I. Tour most likely belongs to the time of its reconstruction into a chapel. This painting by M.I. Rostovtzeff called semi ecclesiastic ${ }^{36}$. The original funerary painting of this tomb includes the remains of a single male figure to the right of the entrance. The same figures of young men are depicted in the tombs of 1853/1904 and 1909; in the latter, the young man still has a burning candle in his hands (Fig. 4, 2). There were also burning candles on both sides of the two beds in the 1905 tomb (Fig. 1, 2). In two tombs, the remains of images of vessels - cantharus on the ceiling of the tomb of 1909 and a vial on the wall of tomb No. 1/1998-1999 are recorded. On the vault of two tombs $(1853 / 1904$ and 2003/2006), there is a Christogram in a wreath, which could have been in four more tombs judging by the remains of the painting ${ }^{37}$.

Thus, the basis of the decorative program of the Chersonesos tombs was primarily floral motifs and birds. In addition to the individual meanings associated with Christian dogmas, these images, presented in a single composition, created a picture of a heavenly paradise. The souls of dead Christians live in the likeness of birds. The presence of the Christogram in the painting, a symbol of Christ's victory over death, further strengthened the belief in his own resurrection in the Kingdom of Heaven. The hope for a paradise existence and the presence of the soul of the deceased among the righteous is also contained in the only epitaph preserved in the tomb of 2003/2006: "Ariston, God rest his soul. Your soul is with the righteous ${ }^{38}$."

The garden of Eden decoration, which expressed the eternal dream of bliss in the afterlife and has been known in art since ancient times, as well as the marble cladding imitation, borrowed from the design of Hellenistic and Roman public buildings and noble houses, were trendy in the Late Roman Empire and were easily perceived and reinterpreted by early Christian art. Elements of the floral and inlay styles, separate artistic

\footnotetext{
${ }^{36}$ Rostovtzeff 1914, 476-479; Zavadskaya 2005, 273-274.

${ }^{37}$ Rostovtzeff 1914, 453-478.

${ }^{38}$ Stupko, Turovskiy, Filippenko 2007, 190.
} 


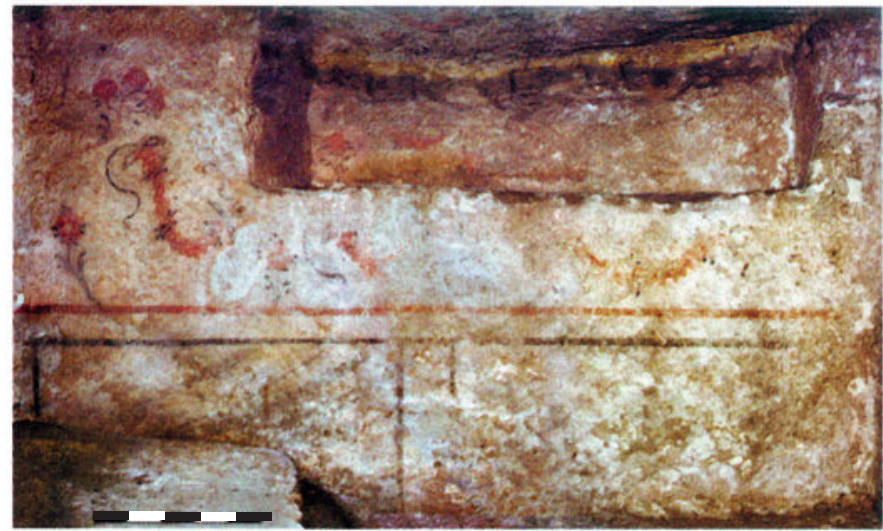

Fig. 3 Chersonesos. Painting of the left wall of tomb No. 1/1998-1999 (photo by: Zubar', Khvorostyanyy 2000, fig. 65, 2)

systems, are found independently or combined in burial paintings from Rome to the Eastern Mediterranean.

In the Roman catacombs, these motifs, extremely numerous and diverse, served primarily as a compliment, a background for multi-figure plot compositions, mythological, iconographic scenes, and individual characters, which formed the basis of the decorative system of catacomb painting ${ }^{39}$. Scenes from the Old and New Testaments, figures of saints and the dead surrounded by the Garden of Eden motifs are presented in the tombs of the $4^{\text {th }}$ century in Pécs (Hungary) and Niš (Serbia) ${ }^{40}$, as well as in several tombs from Thessalonica, the painting of which was sometimes supplemented with marble decoration ${ }^{41}$. The decorative system, in which floral motifs and marble inlay were combined with sculptural painting, has its own examples in the Palestinian East. In a lavish painting of a pagan tomb in Ashkelon (Israel) of the middle of the $3^{\text {rd }}$ century, an idyllic painting of Elysius with a Nile landscape with nymphs and a lush vine, birds, animals, and mythical characters is presented above the imitation marble panels ${ }^{42}$. Above the same row of panels in the tomb of the turn of the $3^{\text {rd }}-4^{\text {th }}$ centuries in Or-ha-Ner (Israel) were numerous flowers, vines, and birds, surrounding 14 medallions with conditional portraits of the buried ${ }^{43}$. Motifs of the Garden of Eden and crosses, as well as the Old Testament story with Daniel in the den of lions, decorated the walls of the Christian tomb of the late $4^{\text {th }}$ - early $5^{\text {th }}$ century in Lohamei ha-Getaoth (Israel) ${ }^{44}$.

A significant variety of decorative systems is demonstrated by the funerary painting of the Necropolis of Thessalonica, in which 78 painted tombs of the $3^{\text {rd }}-7^{\text {th }} / 8^{\text {th }}$ centuries were discovered. Many tombs of the $3^{\text {rd }}-5^{\text {th }}$ centuries, in addition to those mentioned

${ }^{39}$ Ferrua 1991.

${ }^{40}$ Valeva 2001, 185, fig. 450; Mirković 1956.

${ }^{41}$ Marki 2006, 130-156, no. 41, 46, 49, 52, 89. The use of iconographic scenes in the tombs of Thessalonica is considered a result of the Roman artistic tradition (Kuvatova 2017, 128-141).

${ }^{42}$ Michaeli 2001.

${ }^{43}$ Michaeli 1998.

${ }^{44}$ Maayan-Fanar 2010. 


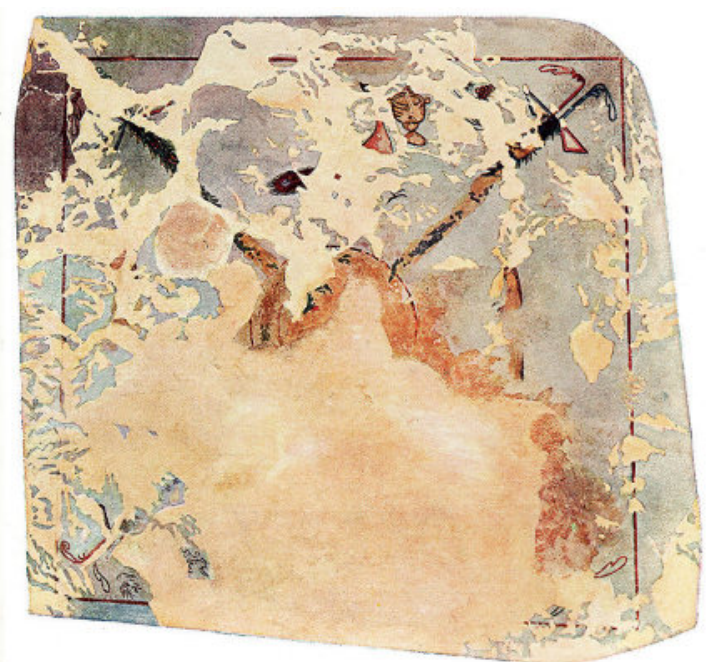

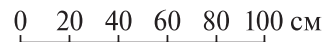

1

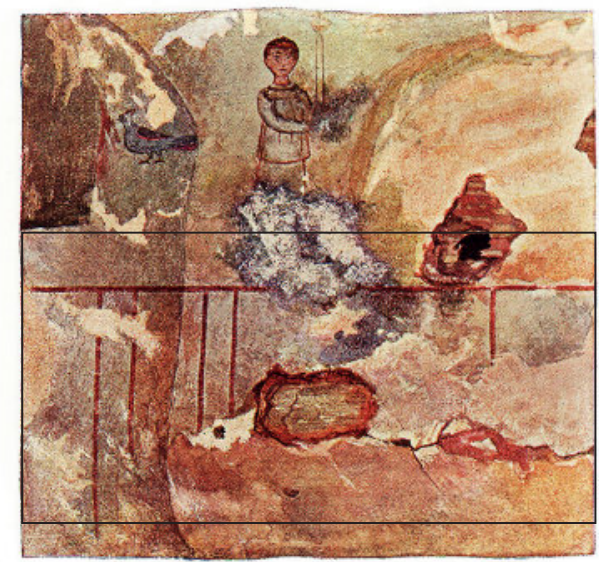

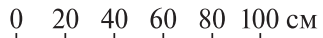

Fig. 4. Chersonesos. Painting of the tomb of 1909: 1 - the ceiling; 2 - the wall of the left and back walls (Fig. by: Rostovtzeff 1913, Tables 105, 1, 2)

above with subject paintings, were decorated only with allegorical paintings of paradise ${ }^{45}$. The decoration of several tombs in the middle of the fourth century consisted exclusively of marble imitations, in one case combined with a circled Christogram ${ }^{46}$. There are also tombs of the 4th century, the decorative system of which combined paradise motifs and marble imitation panels. In one of the tombs, the imitation was replaced by a veneer of natural marble ${ }^{47}$. Thus, the same decorative system was used in these monuments as in the painted tombs of Chersonesos. However, unlike the Chersonesos paintings with a limited set of decorative and symbolic elements freely represented on the surface of the walls, the compositions of the tombs of Thessalonica are very rich in various motifs that occupy almost the entire space of the wall, creating the effect of horror vacui (fear of emptiness). And although modern trends are already evident in Thessalonica painting, manifested, in particular, in a simplified, striving for symmetry and devoid of perspective composition, individual motifs and images, executed very subtly and painterly, demonstrate the preserved classical skills of their performers.

Closer analogies to the Chersonesos paintings both in the set of decorative elements and in the style of their implementation are found on the territory of the Eastern Balkan provinces of Thrace and Dacia, as well as in the western part of Asia Minor. In the funerary paintings of these regions, the most common were floral and plant motifs and images of birds. Several tombs of the second half of the $4^{\text {th }}$ century in Marcianopolis/Devnya, Philippopolis/Plovdiv, and Serdika/Sofia painted garlands, flowers, and birds scattered

\footnotetext{
${ }^{45}$ Marki 2006, 125-189, no. 20-22, 26, 46, 48, 51, 32, 37, 57, 95, et al.

${ }^{46}$ Marki 2006, 173-177, no. 16, 56, 78, 99.

${ }^{47}$ Marki 2006, 159-178, No. 53, 91, 94, Tomb of Telloglio, No. 29.
} 
on the field formed symmetrical composition, in fact, turned into a decorative scheme ${ }^{48}$. A grape-vine, usually originating from acanthus leaves, was also popular, combined with other few floral motifs, sometimes combined with birds. These motifs are represented in the three tombs of the Necropolis of Saint Sofia ${ }^{49}$ with various schematization levels. More naturalistic was the vine with birds and cantharus in the painting of the missing tomb of the western necropolis of Philippopolis ${ }^{50}$.

On the territory of Thrace and Asia Minor, a decorative system was also popular, combining floral decor and marble imitation. Examples are the paintings of tomb No. 7 of the Necropolis of Saint Sofia and the tomb in Hisarya ${ }^{51}$. In St. Sophia's tomb No. 9, the marble panels formed part of a more elaborate program, including busts of the four archangels, a large radiant Latin cross in a wreath in the center of the vaulted ceiling decorated with round caissons, as well as images of four birds and a cantharus ${ }^{52}$.

Close analogies to individual decorative elements and the system as a whole are also found in the burial painting in Sardis. Currently, there are 12 painted tombs, most of which are very similar in style and composition ${ }^{53}$. In Kâgirlik Tepe, one of the tombs preserved the image of a vine with thin branches and triangular clusters ${ }^{54}$, reminiscent of the vine of the Chersonesos tomb of 1905. In the other tombs, the division into the lower and upper zones is recorded. One of the design options for the lower basement part was an imitation of marble cladding. In the tomb of the Flavios Chrysanthios family, the basement panels imitated three types of marble, two of which are comparable to the Chersonesos paintings ${ }^{55}$ (Fig. 5). In particular, the pattern with the brecciated structure in the form of irregular ovals of different sizes is similar to the same motif in the Chersonesos tombs of 1903, 1853/1904, and 1905 (Fig. 1, 2), and the marbling in the form of oblique dark stripes resembles the painting of tombs No. 2/1907 and No. 1/1998-1999. (fig. 3). The same stripes filled the foundation of the so-called "painted tomb" in Sardis ${ }^{56}$. A very close drawing of these two types of marble imitation is also preserved in the already mentioned tomb in Hisarya, and an imitation of brecciated marble is preserved in the St. Sofia tomb No. $7^{57}$. The repertoire of the upper zone of paintings in Sardis was quite monotonous and consisted of stylized garlands and wreaths, scattered flowers, baskets of fruit or flowers, and birds - peacocks and smaller birds. Filled baskets are often depicted as overturned. A similar composition in red color was preserved in the painting of the Chersonesos tomb No. 2/1998-1999. (Fig. 6). It consisted of a wicker basket drawn in several lines, tilted to

${ }^{48}$ Pillinger, Popova, Zimmermann 1999, 19-21, Nr. 9, 21-22, Nr. 11, 46-47, Nr. 36, 64-65, Nr. 47; Miyatev 1925, 36-44, No 5.

${ }^{49}$ Miyatev 1925, 23-35, № 4, 45-66, № 6, 7; Pillinger, Popova, Zimmermann 1999, 62-64, Nr. 46, 65-66, Nr. 48, 66-67, Nr. 49.

${ }^{50}$ Pillinger, Popova, Zimmermann 1999, 47-48, Nr. 37.

${ }^{51}$ Miyatev 1925, 55-67, № 7; Pillinger, Popova, Zimmermann 1999, 48-50, Nr. 38, $66-$ 67, Nr. 49.

${ }^{52}$ Miyatev 1925, 86-105, № 9; Pillinger, Popova, Zimmermann 1999, 68-72, Nr. 51.

${ }^{53}$ Rousseau 2019; Valeva 2001, 176.

${ }^{54}$ Rousseau 1999, 12-13, fig. 18.

${ }^{55}$ Rousseau 2019, 4-7, fig. 3-7.

${ }^{56}$ Rousseau 2019, 7-8, fig. 8-11.

${ }^{57}$ Pillinger, Popova, Zimmermann 1999, Taf. 60, Abb. 98, 99, Taf. 68, Abb. 133. 


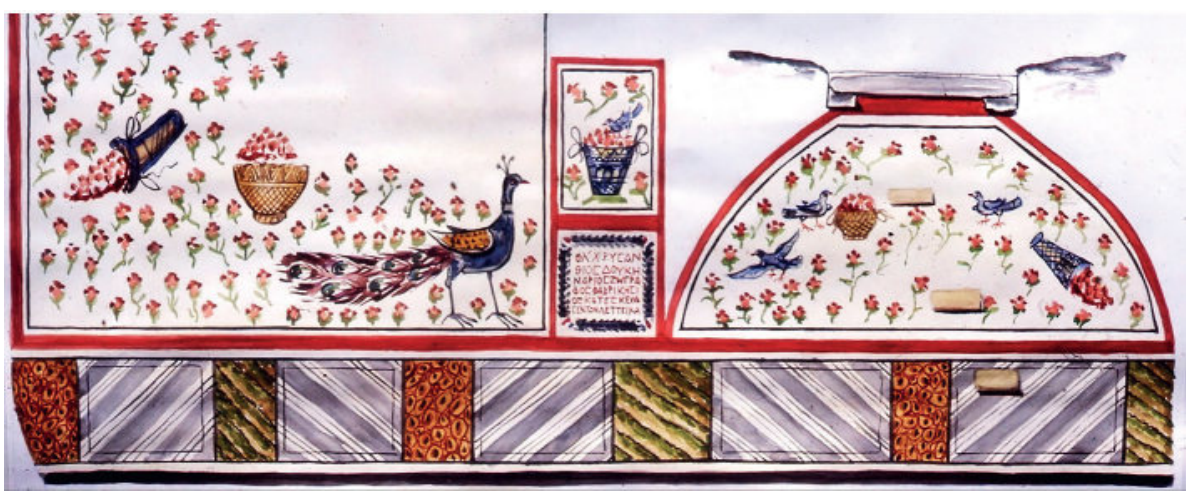

Fig. 5. Sardis. Painting of the tomb of Flavios Chrysanthios, $4^{\text {th }}$ century (fig. by: Rousseau 2019, 5, fig. 4)

the left, with flowers spilling out of it in the form of red spots, and three vertical garlandssplitters located to the right of it, the image of a small bird was preserved between two of them. The shape of the basket has some analogies in Sardis (for example, in tomb 79.2) ${ }^{58}$. Its composition schematically reproduces a more picturesque plot from the $3^{\text {rd }}$ century tomb of the "Seven Sleepers" in Ephesus ${ }^{59}$ (Fig. 7). A vase or basket filled with flowers and tilted to the left with finely drawn weaving is depicted near a red garland. Probably, this composition was popular in the burial painting of this region in the next $4^{\text {th }}$ century.

Despite a generally similar set of floral elements, the Chersonesos paintings have an important feature that distinguishes them from most of the above-mentioned BalkanAsia Minor examples. One of the most popular motifs in Late Antique burial paintings throughout the empire, namely the motif of a flower field, with freely scattered flowers that create a background for other images, was not widely used ${ }^{60}$. M.I. Rostovtzeff noted that for the painting of the eight tombs published by him, images of whole branches or small trees, sometimes with flowers or fruits, are typical but there are no scattered flowers and petals ${ }^{61}$. A flower on a stem with leaves as an independent decorative element is an important part of the decor only in tomb No. 1/1998-199962 (Fig. 3). On the walls, it is presented repeatedly, although not as often as in the flower fields. Probably, flower buds without stems could create a background in the already mentioned composition with an overturned basket in tomb No. 2/1998-1999, as indicated by the preserved red spots here and there ${ }^{63}$ (Fig. 6). In the tomb of 2003/2006, you can also see a resem-

${ }^{58}$ Rousseau 2019, 30, fig. A11.

${ }^{59}$ Valeva 2001, 176, fig. 24; Strocka 2002, 286, Abb. 3; Zimmermann 2011, 386, Abb. 15.

${ }^{60}$ Most often, they were stylized flowers on a stem with leaves. Their numerous examples can be found in the paintings of the tombs of Thessalonica, Veria, Sofia, Silistra, Hisarya, Constanta, Nikaea, Sardis, and many other late-Antique centers (Valeva 2001, 174-176; Marki 2006; Pillinger, Popova, Zimmermann 1999; Rousseau, 2019; et al.).

${ }^{61}$ Rostovtzeff 1914, 462.

${ }^{62}$ Zubar', Khvorostyanyy 2000, 146-147, рис. 65, 1-5.

${ }^{63}$ Zubar', Khvorostyanyy 2000, 146-147, рис. 65 , 6. Color spots imitating flowers and entire flower fields are known, for example, in the painting of the tomb of Marcianopolis (Valeva 2001, fig. 25). 


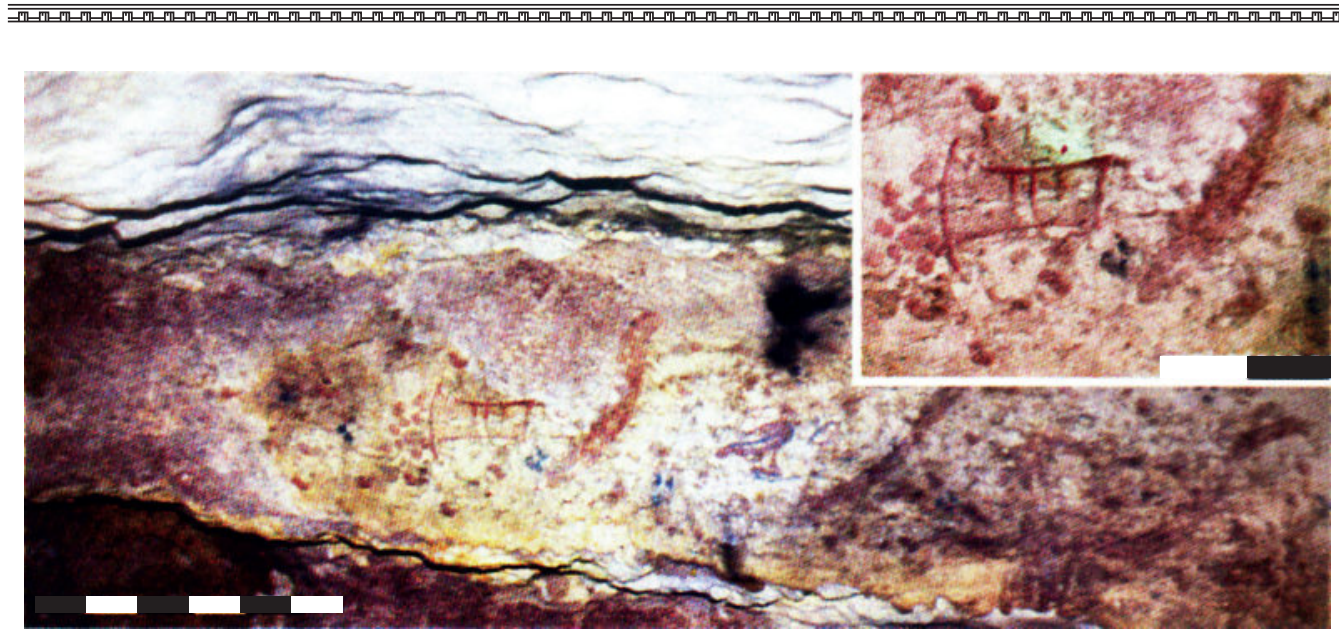

Fig. 6. Chersonesos. Painting of the left wall of tomb No. 2 of 1998-1999 (photo by: Zubar', Khvorostyanyy 2000, fig. 65, 6)

blance of a flower field in the form of several stylized rosette flowers freely scattered on the walls with four heart-shaped petals and thin tendrils between them ${ }^{64}$ (Fig. 2, 1). In a composition with two peacocks in a tomb in the land of N.I. Tour, there were only three symmetrically arranged rosettes of the same type ${ }^{65}$ (Fig. 2, 2). Thus, the Late Roman flower fields in a much-reduced variation found their weak reflection only in the three toms of Chersonesos discovered in our time.

One characteristic feature of the late Antique funerary paintings of Thrace and Asia Minor, essential in searching for similarities to the Chersonesos monuments, is the small number of compositions with human figures. Of the 12 painted tombs in Sardis, the human image, most likely a personification, is preserved on the vault of only one tomb $(07.3)^{66}$. On the territory of Thrace, with a few exceptions, figurative paintings were devoted to a single theme and represented the scene of a burial feast or a procession of servants ${ }^{67}$. The plot of servants going to their masters with offerings was derived from the popular pagan art scene of the burial feast, which in the Late Antique period underwent certain transformations and gradually lost its relevance ${ }^{68}$. Paintings with free-standing servants, usually placed in orthostats, have been preserved in several fourth-century

${ }^{64}$ Stupko, Turovskiy, Filippenko 2007, fig. 2a. This type of rosette flower was very popular in the Late Antique period and is found in various art monuments. The closest analogies in burial painting are the tombs in Viminacium and Brestovik (Serbia), tomb No. 37 in Thessalonica, and No. 7 in Sofia (Valeva 2001, 174, fig. 18, 36; Pillinger, Popova, Zimmermann 1999, Taf. 68, Abb. 133).

${ }^{65}$ Rostovtzeff 1914,475 , рис. 88 , table CVII.

${ }^{66}$ Rousseau 2019, 10-11, fig. 12-14.

${ }^{67}$ Only in tomb No. 9 of the Necropolis of Saint Sofia, busts of archangels with their names in Latin are painted in the four corners of the vault (Miyatev 1925, 86-106). In the tomb of the mid-fourth century in Constance, in addition to the scenes of the funeral meal, there was also a plot with two orants in the Garden of Eden (Valeva 2001, 188, fig. 54).

${ }^{68}$ Valeva 2001, 180-185. 


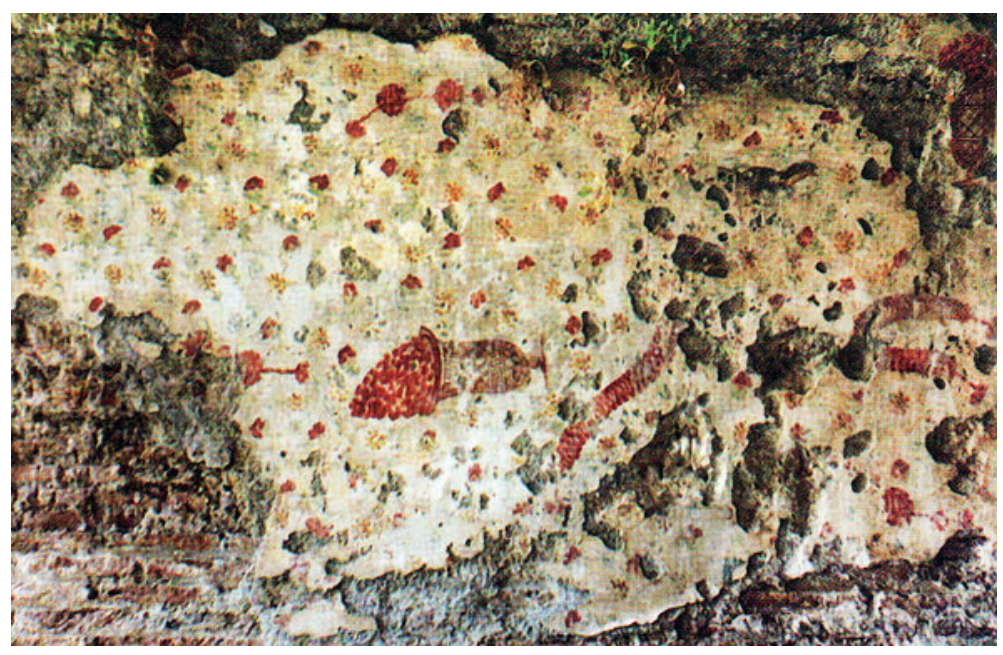

Fig. 7. Ephesus. Painting of the tomb of the "Seven Sleepers", $3^{\text {rd }}$ century (photo by: Valeva 2001, 176, fig. 24; Zimmermann 2011, 386, Abb. 15)

Balkan tombs ${ }^{69}$. The images of the servants, their poses, and clothes in some tombs are very similar. The same type of knee-length, long-sleeved, belted tunic was worn by all the male servants from the tombs of Silistra and Viminacius. The figures of young men in the two Chersonese tombs of 1853/1904 and 1909 are also represented in the same tunics (Fig. 4, 2). The similarity to the Balkan characters also allows them to be considered servants ${ }^{70}$. In the tomb on the ground of N.I. Tour, on the entrance wall, only the feet in sandals of the same figure were preserved. The figures of servants borrowed from the pagan repertoire included in the decorative program of the Chersonesos tombs were intended to emphasize the high social status of their owners, who had already become Christians. Among the Balkan examples with images of servants, only the tomb in Ossenovo, whose painting, executed in a primitive style, included a chrysanthemum in a circle above the entrance, was indisputably Christian ${ }^{71}$.

The image of the Christogram or cross in a wreath, circle or medallion is one of the most common symbols of the new faith in early Christian art in the 4th century, starting from the era of Constantine the Great. At the same time, if in the west of the empire, as well as in the Balkans and in the western part of Asia Minor, the Christogram was more often used at this time, the cross was the dominant symbol in the monuments of Syria, Palestine, and Egypt ${ }^{72}$.

${ }^{69}$ Pillinger, Popova, Zimmermann 1999, 13-16, Nr. 4, 22-28, Nr. 13, 42-46, Nr. 35; Valeva 2001, 182-184, fig. 36, 38.

${ }^{70}$ Zavadskaya 2005, 274-276; 2013, 58-59.

${ }^{71}$ Pillinger, Popova, Zimmermann 1999, 22-28, Nr. 13.

${ }^{72}$ Patrich 2016, 275. In the catalog of tombs with cross-shaped symbols of Yu. Valeva, there are no monuments with the Christogram in the Syro-Palestinian region and Egypt (Valeva 1998, 772-782). Probably, in the $4^{\text {th }}$ - early $5^{\text {th }}$ century, the typical image there was a Latin cross with the letters $\alpha$ and $\omega$ in a lush floral wreath among various motifs of paradise decoration, as, for example, in the tombs of Lohamei ha-Getaoth (Israel) and Gabbari (Alexandria) (MaayanFanar 2010, 77, pl. 4; McKenzie 2007, 239, fig. 405). 


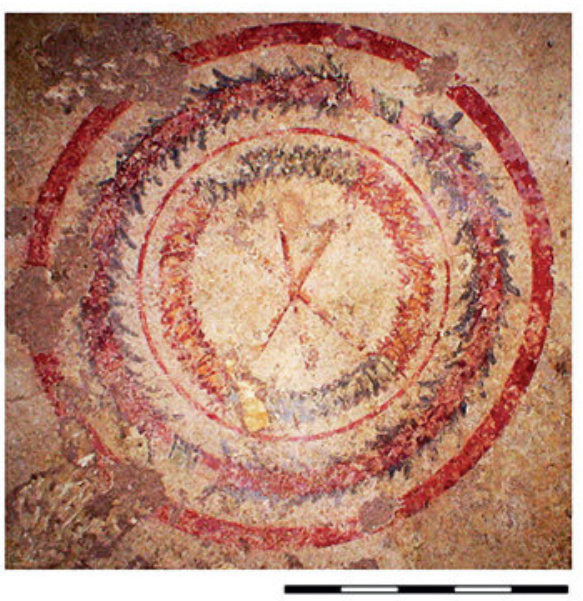

Fig. 8. Chersonesos. Painting of the tomb ceiling of 2003/2006 (photo by Stupko, Turovskiy, Filippenko 2007, fig. 1)

In the tombs of Chersonesos, the main unconditional Christian symbol was the Christogram. It is fully preserved only in the two tombs - 1853/1904 and 2003/2006. On the vault of the tomb of $2003 / 2006$, the monogram of Christ was located in a medallion consisting of a red circle with two floral-deciduous wreaths inscribed in it ${ }^{73}$ (Fig. 8). A very similar medallion of red circles and a wreath between them, also containing a monogram, was on the wall of Tomb No. 4 in Sofia ${ }^{74}$ (Fig. 9). The drawing of the Chersonesos monogram of thin straight red lines is comparable to the same motif in the tombs of Thessalonica ${ }^{75}$ and the "painted tomb" in Sardis, the only one with a chrysanthemum in this necropolis ${ }^{76}$.

On the vault of the tomb of $1853 / 1904$, the chrysanthemum with the letters $\alpha$ and $\omega$ was part of a whole geometric composition consisting of a wreath of laurel leaves surrounding it, from which four straight garlands of the same leaves ran diagonally to the corners. The wreath and garlands were decorated with colored ribbons and ribbons tied at the ends of the garlands in lush bows. The remains of a similar compositional scheme are recorded in four more tombs: 1909 (Fig. 4, 1), 1905, No. 2/1907, and on the land of N.I. Tours in which, according to M.I. Rostovtzeff, could be a chrism ${ }^{77}$. On the vault of the tomb of 1909, probably in each of the segments formed by garlands, there were images of a peacock, a cantharus, and a vine branch with clusters.

The diagonal ceiling decoration system is considered a Roman tradition ${ }^{78}$. Paintings with a central medallion and radially radiating lines or plant garlands from it to the corners emphasized the cross vaults of some rooms in the Roman catacombs ${ }^{79}$. Such a decoration system was very rarely used in tombs with a cylindrical vault, which was the most common type of burial structure in the Balkan-Asia Minor region in the late Roman period. Only in the necropolis of Thessalonica, one of the richest both in the number of painted tombs and in the variety of their decorations is known a single, very picturesque example of the diagonal design of the vault with lush flower garlands and a wreath, with two peacocks and large flower buds on a field dotted with small flowers ${ }^{80}$. Flower fields or painted caissons were more preferable decorations for elongated cylindrical vaults ${ }^{81}$. The choice of a diagonal decorative scheme for the

\footnotetext{
${ }^{73}$ Stupko, Turovskiy, Filippenko 2007, рис. 1.

${ }^{74}$ Miyatev 1925, 23-35, № 4; Pillinger, Popova, Zimmermann 1999, Taf. 66, Abb. 125.

${ }^{75}$ Marki 2006, 159, 173-175, no. 53, 165-167, no. 57.

${ }^{76}$ Rousseau 2019, 7, fig. 7.

77 Rostovtzeff 1914, 453-478.

${ }^{78}$ Rostovtzeff 1914, 454; Valeva 2001, 172.

${ }^{79}$ Examples in the catacomb on Via Latina (Ferrua 1991, 123, fig. 112, 129, fig. 122).

${ }^{80}$ Marki 2006, 158-159, no. 52, fig. 99.

${ }^{81}$ Valeva 2001, 172-173.
} 


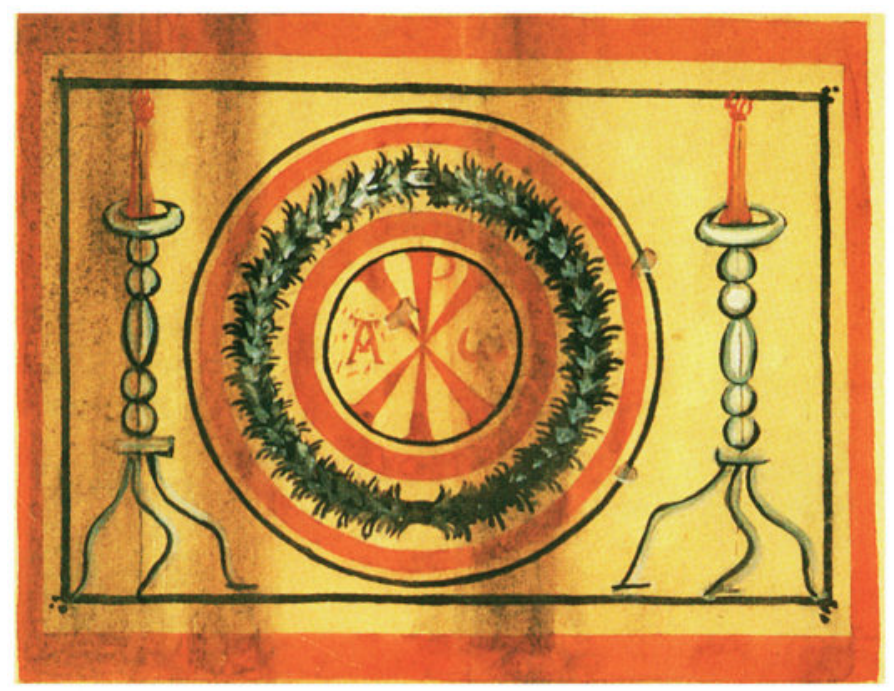

Fig. 9. Serdica/Sophia. Painting of the eastern wall of tomb No. 4 (fig. by: Pillinger, Popova, Zimmermann 1999, Taf. 66, Abb. 125)

Chersonesos tombs could be due to their architecture: for a flat or false-vaulted ceiling with a trapezoidal plan, close to a square, the imitation of a cross vault was the most suitable. To implement this system, the artists used a dry laurel garland popular in Chersonesos, sometimes with red shamrocks interwoven, and a similar wreath tied with colored ribbons and ribbons. As a result, a local version of the ceiling design appeared, which was very popular in the city but did not have close stylistic analogies outside of it.

Of course, the paintings of the early Christian tombs of Chersonesos are part of an extensive collection of monuments of late Antique burial painting. Decorative programs of many burials of this time, expressing, in fact, the universal aspirations of the afterlife, similar to the blooming Garden of Eden, had a universal character and were perceived by different faiths. Explicit religious symbols, such as the cross and the christogram, were not yet mandatory and are therefore relatively rare in Christian burials ${ }^{82}$. The polyvalent nature of these paintings allows us to consider them in the general context of late Antique burial art, regardless of their religious affiliation.

Almost all the artistic motifs and symbols recorded in the paintings of the Chersonesos tombs, as well as the decorative system that combined elements of floral and inlay styles, are found in many regions of the Late Roman Empire, both Western and Eastern. However, the specifics of the artistic repertoire with the absolute dominance of floral and plant motifs and birds and the limited presence of human figures, as well as the simplicity of the composition and the style of painting, in which classical picturesqueness gives way to decorativeness and conventionality - all these features of Chersonesos paintings, find the closest parallels in the eastern Balkan provinces of Thrace and Dacia and the western part of Asia Minor. These geographically close territories on both sides of the Propontis were closely connected. Since

${ }^{82}$ On the peculiarities of the use of cruciform symbols in Early Christian art (Zavadskaya 2009, 104-106). 
the first centuries of our era, a common local culture has been formed over there, in the conditions of active migration processes, a similar socio-economic and political situation, and a constant traditional exchange of artistic ideas ${ }^{83}$. The peculiarity of the artistic culture and art of this region, in particular burial painting, allowed Yu. Valeva to conclude that in the Late Antique period, in parallel with the Roman metropolitan school, these territories were a separate center of artistic production. It is with the artistic culture of this region that the paintings of the early Christian tombs of Chersonesos should be associated.

The masters who painted these monuments followed the already established and well-known decorative and symbolic system and used a certain set of images. However, the observance of established canons did not deprive them of some creative freedom in the composition, the selection of motifs, and their interpretation. Probably, customers could also participate in this process. As a result, all the paintings are individual and are not exactly repeated anywhere. Nevertheless, in some tombs, there are decorative elements executed almost the same way, perhaps demonstrating the hand of one artist, while in other tombs they have a different pattern. Examples are the two types of garlands already mentioned - dry gray-green from laurel leaves and red floral ones and several variations of marble imitation. However, the stylistic diversity in the Chersonesos paintings, probably indicating the work of different masters or teams, is relatively limited and only confirms their belonging to the same artistic tradition. However, these paintings also have some distinctive features that give them a regional specificity. So, what they have in common is a very modest set of decorative elements and, as a rule, very concise and not overloaded with details of the composition. In addition, the variations of some motifs can be considered characteristic of Chersonesos since they do not find exact analogies outside of it. These include the mentioned above laurel garland and the diagonal composition of the ceiling formed from it, which, judging by the remnants of the paint layer, decorated most of the tombs. These features of the Chersonesos paintings allow us to consider them as a local Chersonesos version of the provincial East Balkan and West Asia Minor Late Antique burial paintings.

The introduction of this artistic tradition to Chersonesos from these regions is historically quite natural. Chersonesos had long-standing active trade, military-political, cultural and religious ties with Thrace and Asia Minor ${ }^{84}$. The Diocese of Chersonesos, which most likely arose in the first half of the 70 s of the fourth century under Emperor Valens ${ }^{85}$, was administratively adjacent to the Diocese of Thrace. The signature of its first bishop, Epherius, a participant in the Second Ecumenical Council in Constantinople in 381, was on the list of bishops of the Thracian region of Scythia. At this council, the Christian communities of Thrace were placed under the administration of the Head of the Church of Constantinople (Socr. V. 8) ${ }^{86}$. And in the following centuries, Thrace and Asia Minor, the unifying center of which was Constantinople as a capital, remained for Chersonesos/Cherson the main generators of artistic ideas, the influence of which was reflected in many areas and especially vividly in the church architecture of Cherson and the entire Crimea ${ }^{87}$.

${ }^{83}$ Valeva 1979-1980, 117-129.

${ }^{84}$ Aibabin 2010, 353-356; Zubar' 1994, 141; Kadeev, Sorochan 1989, 57-76; Buyskikh 2008, 238.

85 Zuckerman 1994, 549.

${ }^{86}$ Zavadskaya 2003, 416-417.

${ }^{87}$ Buchwald, Zavadskaya 2013; Zavadskaya 2019. 


\section{References}

Aibabin, A.I. 2010: [Early Byzantine Chersonesos/Cherson]. In: Vizantiya v kontekste mirovoy kultury. Materialy konferentsii, posvyashchennoy pamyati A.V. Bank [Byzantium within the Context of World Culture. Proceedings of the conference dedicated to the memory of A.V. Bank]. Saint Petersburg, 353-379. Айбабин, А.И. Ранневизантийский Херсонес-Херсон. В сб.: Византия в контексте мировой культуры. Материалы конференции, посвященной памяти А.В. Банк. (ТГЭ, LI). СПб., 353-379.

Bianchi Bandinelli, R. 1970: Rome. La fin de l'art antique. L'art de l'Empire romain de Septime Sévère à Théodose $I^{e r}$. Paris.

Bolgov, N.N. 2004: [Syrian cultural influences in the Late Antique Northern Black Sea Region]. In: Prichernomor'e, Krym, Rus'v istorii i kulture: materialy II Sudakskoy mezhdunarodnoy nauchnoy konferentsii (12-16 sentyabrya 2004 g.). Ch. I [Black Sea, Crimea, Russia in History and Culture: Materials of the II Sudak International Scientific Conference (September 12-16.09.2004). Pt. I]. Kiev-Sudak, 17-19.

Болгов, Н.Н. Сирийские культурные влияния в позднеантичном Северном Причерноморье. В сб.: Причерноморье, Крым, Русь в истории и культуре: материалы II Судакской международной научной конференции (12-16 сентября 2004 г.). Ч.І. Киев-Судак, 17-19.

Buchwald, H., Zavadskaya, I. 2013: Early Christian basilicas in Crimea and their numeric proportions. Materialy po arkheologii, istorii i etnografii Tavrii [Materials in Archaeology, History and Ethnography of Tauria] XVIII, 14-48.

Buchwald, H., Zavadskaya, I. Early Christian basilicas in Crimea and their numeric proportions. МАИЭТ ХVIII, 14-48.

Buyskikh, A.V. 2008: Prostranstvennoe razvitie Khersonesa Tavricheskogo v antichnuyu epokhu [Spatial planning development of Tauric Chersonesos in ancient epoch]. Simferopol.

Буйских, А.В. Пространственное развитие Херсонеса Таврического в античную эпоху. (МАИЭТ, Suppl. 5). Симферополь.

Diatroptov, P.D. 1986: [Extension of Christianity in Tauric Chersonesos in the $4^{\text {th }}-6^{\text {th }}$ centuries]. In: Antichnaya grazhdanskaya obshchina [Antique Civil Community]. Moscow, 127-151.

Диатроптов, П.Д. Распространение христианства в Херсонесе Таврическом в IV-VI вв. В сб.: Античная гражданская община. М., 127-151.

Diatroptov, P.D. 2002: [Once again to the question of the dating of mural painting of Chersonesos Christian tombs]. In: Tserkovnaya arkheologiya Yuzhnoy Rusi: sbornik materialov mezhdunarodnoy konferentsii "Tserkovnaya arkheologiya: problemy, poiski, otrkytiya" [Church Archeology of South Russia: Collection of Materials of the International Conference "Church Archeology: Problems, Searches, Discoveries"]. Simferopol, 34-37.

Диатроптов, П.Д. Еще раз к вопросу о датировке росписей херсонесских христианских склепов. В сб.: Церковная археология Южной Руси: сборник материалов международной конференции «Церковная археология: проблемы, поиски, открытия» (Севастополь, 2001 г.). Симферополь, 34-37.

Elsner, J. 2002: The birth of late antiquity: Riegl and Strzygowski in 1901. Art History 25/3, 358-379.

Ferrua, A. 1991: The Unknown Catacomb. A Unique Discovery of Early Christian Art. Transl. by I. Inglis. New Lanark.

Filippov, A.E. 2009: [Painting of the early Christian tombs of Tauric Chersonesos in the context of artistic tradition: synthesis with architecture, symbolism, liturgical basis]. In: S.A. Belyaev (ed.), Ocherki po istorii khristianskogo Khersonesa. T. I, 1. Khersones khristianskiy [Essays on the History of Christian Chersonesos. Vol. I, 1. Chersonesos Christian]. Saint Petersburg, 193-318.

Филиппов, А.Е. Росписи раннехристианских склепов Херсонеса Таврического в контексте художественной традиции: синтез с архитектурой, символика, литургическая основа. В сб.:

С.А. Беляев (ред.), Очерки по истории христианского Херсонеса. Т. I, 1. Херсонес христианский. СПб., 193-318.

Fomin, M.V. 2014: [On the problem of the formation of an Early Christian artistic tradition in Chersonesos of the $4^{\text {th }}-5^{\text {th }}$ centuries]. Visnyk Harkivs'kogo nacional'nogo universytetu im. V.N. Karazina. Serija «Istorija» [The Journal of V.N. Karazin Kharkiv National University. Series: History] 1117/48, 38-46. 
Фомин, М.В. О проблеме формирования раннехристианской художественной традиции в Херсонесе IV-V вв. Вісник Харківського національного університету ім. В. Н. Каразіна. Серія «Історія» 1117/48, 38-46.

Grabar, A. 1946: Martyrium. Recherches sur le culte des reliques et l'art chrétien antique. Vol. II: Iconographie. Paris.

Grabar, A. 1972: Le tiers monde de l'Antiquité à l'école de l'art classique et son rôle dans la formation de l'art du Moyen Age. Revue de l'art 18, 8-25.

Kadeev, V.I., Sorochan, S.B. 1989: Ekonomicheskie svyazi antichnykh gorodov Severnogo Prichernomor'ya v Iv. do n.e. - Vv. n.e. (na materialakh Khersonesa) [Economic Contacts of the Ancient Cities of the Northern Black Sea Region in the $1^{\text {st }}$ Cent. BC $-5^{\text {th }}$ Cent. AD. (Based on the Materials from Chersonesos)]. Khar'kov.

Кадеев, В.И., Сорочан, С.Б. Экономические связи античных городов Северного Причерноморья в I в. до н.э. - V в. н.э. (на материалах Херсонеса). Харьков.

Khrushkova, L.G. 2005: [On the beginning of the Christian Tauric Chersonesos: a cross-shaped church in the main cemetery]. In: Sugdeyskiy sbornik. Vyp. II [Sugdaia collection papers. Issue II]. KievSudak, 393-420.

Хрушкова, Л.Г. О начале христианского Херсонеса Таврического: крестовидная церковь на главном кладбище. В сб.: Сугдейский сборник. Вып. II. Киев-Судак, 393-420.

Khrushkova, L.G. 2008: [On the paintings in Early Christian tombs in the Crimea: one hundred years after Mikhail Rostovtzeff]. In: Vizantiya v kontekste mirovoy kultury. Materialy konferentsii, posvyashchennoy pamyati A.V. Bank [Byzantium Within the Context of World Culture. Transactions of the State Hermitage Museum] Saint Petersburg, 121-132.

Хрушкова, Л.Г. О живописи раннехристианских склепов в Крыму: сто лет после Михаила Ивановича Ростовцева. В сб.: Византия в контексте мировой культуры. Материалы конференции, посвященной памяти А.В. Банк. (ТГЭ, XLII). СПб., 121-132.

Kitzinger, E. 1977: Byzantine Art in the Making. Main Lines of Stylistic Development in Mediterranean Art. $3^{\text {rd }}-7^{\text {h }}$ Cent. London.

Kuvatova, V. 2017: Early Christian funerary painting in Thessaloniki. Macedonian and Roman traditions. In: N.A. Nalimova, T.P. Kishbali, A.V. Zacharova (eds.), Makedoniya - Rim - Vizantiya: iskusstvo Severnoy Gretsii ot antichnosti do srednikh vekov: materialy nauchnoy konferentsii [Macedonia - Rome - Byzantium: the Art of Northern Greece from Antiquity to the Middle Ages: Proceedings of the Scientific Conference]. Moscow, 128-141.

Куватова, В. Early Christian funerary painting in Thessaloniki. Macedonian and Roman traditions. В сб.: Н.А. Налимова, Т.П. Кишбали, А.В. Захарова (ред.), Македония - Рим Византия: искусство Северной Греции от античности до средних веков: материалы научной конференции. М., 128-141.

Maayan-Fanar, E. 2010: An early Christian tomb at Lohamei HaGetaot: formation of christological symbolism. Eastern Christian Art 7, 71-89.

Marki, E. 2006: E nekropole tes Tkhessalonikes stous usteroromaikus kai palyaiokhristianikus khronus (mesa tu 3 u eos mesa tu 8 u aj. m.kh.) [The Necropolis of Thessaloniki in the Late Roman and Early Christian Periods (from the Middle of the $3^{\text {rd }}$ Century to the Middle of the $8^{\text {th }}$ Century AD)].

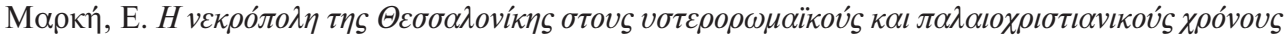

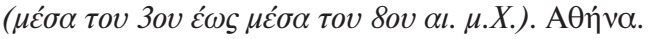

McKenzie, J. 2007: The Architecture of Alexandria and Egypt c. 300 BC to AD 700. London.

Meshcheryakov, V.F. 1978: [About the time of the Appearance of Christianity in the Tauric Chersonesos]. In: Aktualnye problemy izucheniya istorii religii i ateizma [Actual Problems of Studying of History of Religion and Atheism]. Leningrad, 121-134.

Мещеряков, В.Ф. О времени появления христианства в Херсонесе Таврическом. В сб.: Актуальные проблемы изучения истории религии и атеизма. Л., 121-134.

Michaeli, T. 1998: The pictorial program of the tomb near Kibbutz Or-ha-Ner in Israel. Assaph Studies in Art History 3, 37-76.

Michaeli, T. 2001: The iconographic and symbolism of the tomb of the Nymphs at Ashkelon. In: A. Barbet (ed.), La peinture funéraire antique: IVe siècle av. J.-C. - IV siècle ap. J.-C.: actes du VII Colloque de l'Association Internationale pour la peinture mural antique (6-10 Octobre 1998, SaintRomain-en-Gal - Vienne). Paris, 163-170. 
Miyatev, K. 1925: Dekorativnata zhivopis na Sofiyskiya nekropol [Decorative Painting of the Sofia Necropolis]. Sofia.

Миятев, К. Декоративната живопись на Софийския некропол. София.

Mirković, L. 1956: La nécropole paléochrétienne de Niš. Archeologia Jugoslavica II, 85-100.

Pergola, A. 2010: La discussa scena delle donne al sepolcro nel battistero di Dura Europos. Alle origini dell'iconografia della resurrezione di Cristo. Rivista di Archeologia Cristiana 86, 315-352.

Patrich, J. 2016: The early Christianization of the Holy Land - the archaeological evidence. In: Acta XVI Congressus Internationalis Archaeologiae Christianae. Romae (22-28.9.2013). Costantino e i Costantinidi: l'innovazione costantiniana, le sue radici e i suoi sviluppo. Pars I. Vaticano, 265-293.

Pillinger, R., Popova, V., Zimmermann, B. (Hrsg.) 1999: Corpus der spätantiken und frühchristlichen Wandmalereien Bulgariens. (Schriften der Balkankommission, Antiquarische Abteilung, 21). Wien.

Rishnjak, O., Sadova, O., Turovs'kij, E., Filippenko, A. 2012: Nekropol' Hersonesa Tavrijs'kogo. Novi storinky v istorii' doslidzhen' [Necropolis of Chersonesos Tauric. New pages in the History of Research]. Lviv. Рішняк, О., Садова, О., Туровський, Є., Філіппенко, А. Некрополь Херсонеса Таврійського. Нові сторінки в історії досліджень. Львів.

Rostovtzeff, M.I. 1913: Antichnaya dekorativnaya zhivopis' na yuge Rossii. Atlas [Antique Decorative Painting in the South of Russia. An Atlas]. Saint Petersburg.

Ростовцев, М.И. Античная декоративная живопись на юге России. Атлас. СПб.

Rostovtzeff, M.I. 1914: Antichnaya dekorativnaya zhivopis' na yuge Rossii. T.I. Opisanie i issledovanie pamyatnikov [Antique Decorative Painting in the South of Russia. Text. Vol. I. Description and Researches of the Monuments]. Saint Petersburg.

Ростовцев, М.И. Античная декоративная живопись на юге России. Т.І. Описание и исследование памятников. СПб.

Rousseau, V. 2019: Reflection, ritual, and memory in the Late Roman painted Hypogea at Sardis. Arts 8/103, 1-36. URL: https://www.mdpi.com/2076-0752/8/3/103/htm; дата обращения: 23.04.2021.

Strocka, V.M. 2002: Die Fresken von Hanghaus 2 - ein Vierteljahrhundert später. Jahreshefte des Österreichischen Archäologischen Institutes in Wien 71, 285-298.

Strzygowski, J. 1901: Orient oder Rom: Beitrag zur Geschichte der spätantiken und frühchristlichen Kunst. Leipzig.

Stupko, M.V., Turovskiy, E. Ya., Filippenko, A.A. 2007: [On the fate of the painted tombs of the first Christians of Chersonesos]. In: Sacrum et Profanum. Vyp. III. Nebesnye patrony i zemnye sluzhiteli kulta [Sacrum et Profanum. Issue III. Heavenly Patrons and Terrestrial Ministers of Cult]. Sevastopol, 189-192.

Ступко, М.В., Туровский, Е.Я., Филиппенко, А.А. О судьбах расписных склепов первых христиан Херсонеса. В сб.: Sacrum et Profanum. Вып. III. Небесные патроны и земные служители культа. Севастополь, 189-192.

Turovskiy, E. Ya., Filippenko, A.A. 2008: [Chronology of the tombs of the Early Christians of the Chersonesos necropolis (in the light of excavations of 2006)]. Materialy po arkheologii i istorii antichnogo i srednevekovogo Kryma [Materials in Archaeology and History of Ancient and Medieval Crimea] I, 45-48.

Туровский, Е.Я., Филиппенко, А.А. Хронология склепов ранних христиан некрополя Херсонеса (в свете данных раскопок 2006 г.). Материалы по археологии и истории античного и средневекового Крыма I, 45-48.

Valeva, J. 1979-1980: Sur certaines particularités des hypogées paléochrétiens des terres et leurs analogues en Asie Mineure. Anatolica VII, 117-150.

Valeva, J. 1998: Les tombeaux ornés de croix et chrismes peints. In: Acta XIII Congressus internatinalis archaeologiae christianae (Split-Porec, 25.9. -1.10.1994) III. Vaticano, 761-786.

Valeva, J. 2001: La peinture funéraire dans les provinces orientales de l'Empire Romain dans l'Antiquité tardive. Hortus Artium Medievalium 7, 167-208.

Zavadskaya, I.A. 2003: [Conversation to Christianity in early Byzantine Chersonesos (the $4^{\text {th }}-6^{\text {th }}$ centuries)]. Materialy po arkheologii, istorii i etnografii Tavrii [Materials in Archaeology, History and Ethnography of Tauria] X, 402-426.

Завадская, И.А. Христианизация ранневизантийского Херсонеса (IV-VI вв.). МАИЭТ X, 402-426. 
Zavadskaya, I.A. 2005: [Decorative-symbolic system of painting in Chersonesos Christian tombs: aspects of chronology and genesis]. Materialy po arkheologii, istorii i etnografii Tavrii [Materials in Archaeology, History and Ethnography of Tauria] XI, 258-288.

Завадская, И.А. Декоративно-символическая система росписи херсонесских христианских склепов: проблемы хронологии и генезиса. МАИЭТ XI, 258-288.

Zavadskaya, I.A. 2009: [Christian painted tombs of Crimea in the context of funeral painting development in early Byzantine period]. Materialy po arkheologii, istorii i etnografii Tavrii [Materials in Archaeology, History and Ethnography of Tauria] XV, 89-131.

Завадская, И.А. Христианские расписные склепы Крыма в контексте развития погребальной росписи в ранневизантийский период. МАИЭТ ХV, 89-131.

Zavadskaya, I.A. 2013: Early Christian painted tombs in Crimea. Mitteilungen zur Christlichen Archäologie 19, 41-67.

Zavadskaya, I.A. 2019: [Numeric proportions of the early Byzantine basilicas of Chersonesos]. Materialy po arkheologii, istorii i etnografii Tavrii [Materials in Archaeology, History and Ethnography of Tauria] XXIV, 135-159.

Завадская, И.А. Числовые пропорции ранневизантийских базилик Херсонеса. МАИЭТ XXIV, 135-159.

Zimmermann, N. 2011: Das Sieben-Schläfer-Zömeterium in Ephesos. Neue Forschungen zu Baugeschichte und Ausstattung eines ungewöhnlichen Bestattungskomplexes. Jahreshefte des Österreichischen Archäologischen Institutes in Wien 80, 365-407.

Zubar', V.M. 1982: Nekropol Khersonesa Tavricheskogo I-IVvv.n.e. [Necropolis of Tauric Chersonesos of the $1^{\text {th }}-4^{\text {th }}$ Cent. $\left.A D\right]$. Kiev.

Зубарь, В.М. Некрополь Херсонеса Таврического I-IVвв.н.э. Киев.

Zubar', V.M. 1994: Khersones Tavricheskiy i Rimskaya imperiya. Ocherki voenno-politicheskoy istorii [Tauric Chersonesos and Roman Empire. Essays on Military Political History]. Kiev.

Зубарь, В.М. Херсонес Таврический и Римская империя. Очерки военно-политической истории. Киев.

Zubar', V.M., Khvorostyanyy, A.I. 2000: Ot yazychestva k khristianstvu. Nachal'nyy etap proniknoveniya $i$ utverzhdeniya khristianstva na yuge Urkainy (vtoraya polovina III - pervaya polovina VI v.) [From Paganism to Christianity. The initial Stage of Penetration and Confirmation of Christianity in the south of Ukraine (the Second Half of the $3^{\text {rd }}-$ the First Half of the $6^{\text {th }}$ Cent.]. Kiev.

Зубарь, В.М., Хворостяный, А.И. От язычества к христианству. Начальный этап проникновения и утверждения христианства на юге Украины (вторая половина III - первая половина VI в.). Киев.

Zuckerman, C. 1994: [Bishops and a garrison of Cherson in the $4^{\text {th }}$ century]. Materialy po arkheologii $i$ istorii antichnogo i srednevekovogo Kryma [Materials in Archaeology and History of Ancient and Medieval Crimea] IV, 545-561.

Цукерман, К. Епископы и гарнизон Херсона в IV в. МАИЭТ IV, 545-561. 